\title{
MODIFICATION OF SURFACE ROUGHNESS AND Area of FeCrAl SubSTRATe for CATAlytic Converter USING ULTRASONIC TREATMENT
}

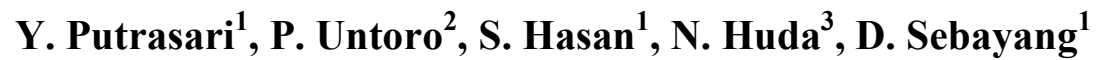 \\ ${ }^{1}$ Advanced Manufacturing and Materials Centre (AMMC), Faculty of Mechanical and Manufacturing Engineering, \\ University Tun Hussein Onn Malaysia (UTHM) \\ Parit Raja, Batu Pahat 86400, Malaysia \\ y.putrasari@gmail.com; sulaiman@uthm.edu.my; darwin@uthm.edu.my \\ ${ }^{2}$ Centre for Technology of Nuclear Industry Materials - National Nuclear Energy Agency (BATAN) \\ Kawasan Puspiptek Gd. 71, Serpong \\ Tangerang 15314, Indonesia \\ untoro@batan.go.id \\ ${ }^{3}$ Research Centre for Electrical Power and Mechatronics - Indonesian Institute of Sciences (LIPI) \\ Komp. LIPI Bandung, J1 Sangkuriang, Gd 20, Lt 2, Bandung \\ Jawa Barat 40135, Indonesia. \\ naili.huda@lipi.go.id
}

Diterima: 26 Juni 2010; Direvisi: 16 September 2010; Disetujui: 13 Desember 2010; Terbit online: 24 Desember 2010.

\begin{abstract}
Abstrak
Kekasaran dan luas permukaan memainkan peranan penting terutama dalam deposisi dan reaksi katalis pada substrat catalytic converter. Tujuan makalah ini adalah untuk menunjukkan modifikasi kekasaran dan luas permukaan substrat FeCrAl untuk catalytic converter menggunakan metode ultrasonik. Metode dilakukan dengan memproses $\mathrm{FeCrAl}$ dalam piranti ultrasonic cleaning bath $35 \mathrm{kHz}$ dalam waktu 10 menit. Kekasaran permukaan, morfologi, dan komponen kimia dari substrat catalytic converter FeCrAl setelah proses ultrasonik dianalisis menggunakan atomic force microscope (AFM) dan diamati dengan scanning electron microscope (SEM) dikombinasikan dengan energy dispersive $x$-ray spectroscopy (EDS). Perlakuan ultrasonik dibantu dengan serbuk $\mathrm{Al}_{2} \mathrm{O}_{3}$ berhasil meningkatkan kekasaran dan luas permukaan FeCrAl lebih baik daripada serbuk $\mathrm{SiC}$.
\end{abstract}

Kata kunci: Permukaan, Perlakuan, Kekasaran, FeCrAl, Substrat, Catalytic, Converter, Ultrasonic.

\begin{abstract}
Surface roughness and area play important role especially in deposition and reaction of the catalyst in the catalytic converter substrate. The aim of this paper is to show the modification of surface roughness and area of FeCrAl substrate for catalytic converter using ultrasonic method. The method was conducted by agitating the $\mathrm{FeCrAl}$ in 10 minutes $35 \mathrm{kHz}$ ultrasonic cleaning bath. The surface roughness, morphology, and chemical components of FeCrAl catalytic converter substrate after ultrasonic treatment were analyzed using atomic force microscope (AFM) and examined with scanning electron microscope (SEM) in combination with energy dispersive $X$-ray spectroscopy (EDS). The ultrasonic treatment assisted with $\mathrm{Al}_{2} \mathrm{O}_{3}$ powders successfully increased the roughness and surface area of FeCrAl better than SiC powders.
\end{abstract}

Keywords: Surface, Treatment, Roughness, FeCrAl, Substrate, Catalytic, Converter, Ultrasonic.

\section{INTRODUCTION}

$\mathrm{FeCrAl}$ has been used for fabrication of high temperatures applications components: heating elements, fire grid and honeycomb (substrate) catalytic converters for automotive exhausts. The surface area of substrate plays important role in deposition and reaction of the catalyst $[1,2,3]$. The honey-comb manufactured is of the efforts to increase the amount of surface area available to support the catalyst, and therefore is often called a "catalyst support" $[3,4]$. Other is to create washcoat, when developed on the substrate, forms a rough, irregular surface, which has a far greater surface area compared to the flat one, which then gives the converter substrate a larger surface area, and therefore more possible places for active precious metal sites $[3,4,5,6]$. Mellali [7] studied the influence of substrate roughness and temperature on the adhesion/cohesion of alumina coatings, when starting with a cold substrate $\left(<100^{\circ} \mathrm{C}\right)$ the adhesion/cohesion increases almost linear with the substrate roughness. Henke [8] has used surface roughness measurements to estimate surface area on 
substrates. Surfaces can be roughened or smoothened using various techniques including chemical deposition, grinding, polishing, and chemical etching [9]. The innovative approach for surface modification is ultrasonic treatment. Panin [10] studied the effect of ultrasonic treatment on mechanical behavior of titanium and steel specimens. The ultrasonic treatment used by Panin was done by exciting ultrasonic oscillations within a treating tool. The oscillation amplitude and frequency of waveguide that used were $15 \mu \mathrm{m}$ and $24 \mathrm{kHz}$. Zhang [11] used ultrasonic horn type with the frequency and power of the ultrasound were set constant at 25 $\mathrm{kHz}$ and $100 \mathrm{~W}$ respectively, for surface treatment of magnesium hydroxide to improve its dispersion in organic phase. The transducer of ultrasound with frequency of $20 \mathrm{kHz}$ was applied by Liu [12] to the aramid/epoxy composites when it was just pulled off from the resin bath to enhance its adhesion. Paniwnyk [13] has already shown that electronics materials can be surface modified using ultrasound in water medium. Paniwnyk, suggested that a rough, debris free surface, is important for optimal adhesion and that ultrasound does achieve surface modification at low temperatures of $40^{\circ} \mathrm{C}$ in chemical free, green and environmentally friendly deionised water. In our previous effort $[14,15,16]$, the influence of ultrasonic assisted with $\mathrm{SiC}$ or $\mathrm{Al}_{2} \mathrm{O}_{3}$ powders on $\mathrm{FeCrAl}$ substrate to high temperature resistance and $\mathrm{NiO}$ catalyst development has been discussed. The ultrasonic technique successfully increased the high temperature resistance of $\mathrm{FeCrAl}$ substrate and homogeneity of nickel electroplating layer. However, the roughness and surface area of $\mathrm{FeCrAl}$ after ultrasonic treatment still needed special investigation. Therefore, in this study, the investigations of modification of surface roughness and area of $\mathrm{FeCrAl}$ substrate for catalytic converter by ultrasonic treatment were conducted. The discussions in this paper are focused on three following issues.

Roughness, as a measure of surface topography commonly occurs in the form of scratches, digs, pits, dust particles, polishing marks on optical surfaces, machining marks on machined surfaces, granularity or crystallites in films deposited on surfaces, undulations left by chemical etching or electropolishing, or marks left by rollers on sheet stock [8]. In this research, ultrasonic approach assisted with $\mathrm{SiC}$ and/or $\mathrm{Al}_{2} \mathrm{O}_{3}$ powders was expected to tune the surface roughness of FeCrAl substrate. The surface roughness was created to obtain the good quality for the next catalyst coating process on the $\mathrm{FeCrAl}$ substrate as explained in our previous papers [14-16]. surface roughness was related to coating adhesion/cohesion of materials [7].

Ultrasonic wave or sound will generate cavitation bubbles in a liquid system [18]. Then, the explosion of the cavitation bubbles will produce a jet flash energy that can damage the surface of a solid material. In this work, slurring of $\mathrm{SiC}$ or $\mathrm{Al}_{2} \mathrm{O}_{3}$ powders in ultrasonic media liquid was expected to assist the process of surface destruction. It is estimated that the particles of the powders driven by the jet flash energy would hit the surface of the material (FeCrAl). Therefore, the irregular surface roughness occurs. Due to the higher hardness property of $\mathrm{SiC}$, it was expected that ultrasonic treatment with $\mathrm{SiC}$ would produce higher roughness to $\mathrm{FeCrAl}$.

Atomic force microscopy (AFM), is one member of a family of techniques that provides images of surface topography by mechanically moving a probe across the sample to detect the contours of the surface and enables one to detect surface morphology, nanoscale structures and molecular and atomic scale lattices [8]. Refer to literature [8], the AFM was chosen for the analysis of surface roughness and estimation of surface area of fused silica and glass substrates. This work used similar approach to calculate the surface area of FeCrAl substrate. The approach assumed that all morphology grains were nodules on $\mathrm{FeCrAl}$ substrate in half of sphere form. Then, the mean area taken from AFM was assumed as area of circles with diameter same as the sphere. The half of sphere surface area was then calculated using sphere surface area formula.

\section{EXPERIMENT}

\section{A. Materials}

The FeCrAl foils (Aluchrom Yhf) with 0.1 $\mathrm{mm}$ thickness were used as substrate in this experiment. The chemicals components of this foil are presented in Table 1.

Table 1.

Chemical components of Aluchrom Yhf (wt-\%) [17].

\begin{tabular}{|c|c|c|c|c|c|c|c|c|c|c|c|}
\hline & $\mathbf{N i}$ & $\mathrm{Cr}$ & $\mathrm{Fe}$ & C & Mn & $\mathbf{S i}$ & Al & $\mathbf{Z r}$ & $\mathbf{Y}$ & Hf & $\mathbf{N}$ \\
\hline $\min$ & - & 19.0 & \multirow{2}{*}{ bal } & - & - & - & 5.5 & - & - & - & - \\
\hline $\max$ & 0.3 & 22.0 & & 0.05 & 0.50 & 0.50 & 6.5 & 0.07 & 0.10 & 0.10 & 0.01 \\
\hline
\end{tabular}


The substrate was prepared by cutting FeCrAl foils into $1 \mathrm{~cm} \times 2 \mathrm{~cm}$. The water and methanol were applied as medium for ultrasonic treatment. The $\mathrm{SiC}$ and $\mathrm{Al}_{2} \mathrm{O}_{3}$ powders with particle size $\leq$ $90 \mu \mathrm{m}$ were provided to assist the ultrasonic treatment. These materials were supplied by Syarikat Sainfik Bersatu, Sdn. Bhd.

\section{B. Ultrasonic treatment}

The ultrasonic cleaning bath Laborette 17 was applied to the FeCrAl foils treatment. The voltage $230 \mathrm{~V} / \mathrm{I} \sim$, input power $2 \times 240 \mathrm{~W} /$ period, frequency $50-60 \mathrm{~Hz}$ and the ultrasound frequency $35 \mathrm{kHz}$ are the technical data. The bath was fully filled with water due to ultrasonic irradiation media. The specimens were put into a beaker which consists of methanol mixed with $\mathrm{SiC}$ and/or $\mathrm{Al}_{2} \mathrm{O}_{3}$ powders as liquid solution. The 0.2 $\mathrm{mg} / \mathrm{ml}$ concentration of solution could be made by slurring $20 \mathrm{mg} \mathrm{SiC}$ or $\mathrm{Al}_{2} \mathrm{O}_{3}$ powders into 100 $\mathrm{ml}$ methanol. The beaker filled with slurry and $\mathrm{FeCrAl}$ foils then immersed into the ultrasonic bath. The FeCrAl then sonicated for 10 minutes. The illustration of ultrasonic treatment was presented in Figure 1. The specimens then dried in atmospheric condition.

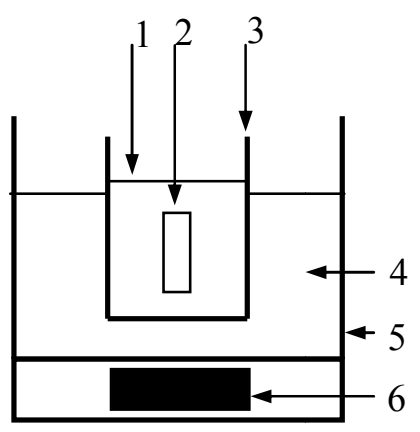

Figure 1. Schematic Diagram of ultrasonic treatment; (1) Methanol; (2) Specimen; (3) Beaker; (4) Water; (5) Bath; (6) Ultrasonic source.

\section{Surface characterization}

Atomic force microscope (AFM) images of the $\mathrm{FeCrAl}, \mathrm{FeCrAl}$ under ultrasonic treatment with $\mathrm{SiC}$, and $\mathrm{Al}_{2} \mathrm{O}_{3}$ were collected using a XE100 Park Systems atomic force microscope (Park Systems Corp). The effect of ultrasonic on the FeCrAl substrate was examined using the result from imaging a region on the sample before and after the ultrasonic treatment. The roughness measurement was taken using horizontal straight line mode. The roughness profiles were presented to clarify the roughness phenomenon caused by ultrasonic treatment on FeCrAl surface. The mean roughness $(\mathrm{Ra})$ was resulted from a random $100 \mu \mathrm{m} 2$ scan area of specimens. The Ra of each specimen was presented as the reported roughness. The 3D images from AFM were displayed to analyze the topography of each specimen. The grain area $\left(\mu \mathrm{m}^{2}\right)$ as $2 \mathrm{D}$ image was measured in AFM analysis to calculate the total surface area of specimen. The scanned surface areas of specimen were calculated by sphere surface area approach. The microstructure and chemical components on surface of $\mathrm{FeCrAl}$ before and after ultrasonic treatment were investigated using JEOL scanning electron microscopy (SEM) model JSM-6380LA in combination with energy dispersive X-ray spectroscopy (EDS).

\section{RESUlT AND DISCUSSION}

\section{A. Influence of Ultrasonic Treatment on Surface Roughness of FeCrAl Substrate}

Figure 2 shows the atomic force microscope (AFM) roughness profile of the $\mathrm{FeCrAl}$ (a) untreated, (b) ultrasonic treatment with $\mathrm{SiC}$, and (c) ultrasonic treatment with $\mathrm{Al}_{2} \mathrm{O}_{3}$. The profiles were taken by AFM random scanning from 10 $\mu \mathrm{m}$ long area of FeCrAl. From these profiles, it can be seen that the highest, medium, and lowest gap between peaks and valley occurred on FeCrAl untreated, treatment with $\mathrm{Al}_{2} \mathrm{O}_{3}$ and with $\mathrm{SiC}$, respectively. The means roughness of these FeCrAl presented in Table 2.

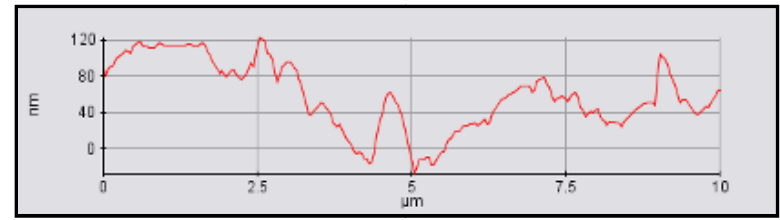

(a)

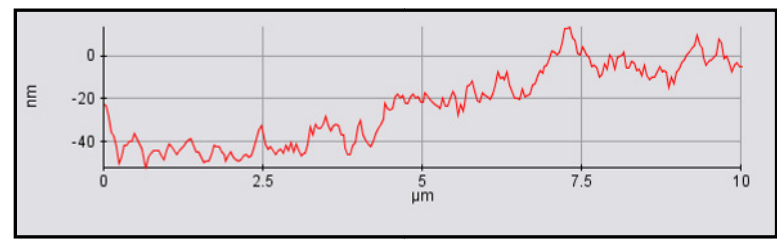

(b)

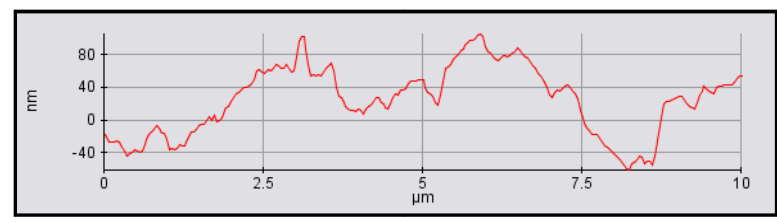

(c)

Figure 2. Roughness profile of $\mathrm{FeCrAl}$ a) untreated, b) ultrasonic treatment with $\mathrm{SiC}$, c) ultrasonic treatment with $\mathrm{Al}_{2} \mathrm{O}_{3}$.

The mean roughness of each specimen was resulted from roughness analysis using horizontal 
straight line method on random position of $10 \mu \mathrm{m}$ $\mathrm{x} 10 \mu \mathrm{m}$ AFM image. The most completed results were observed using the AFM 3D image. The 3D image for representing the visualization of different topography from each specimen was displayed on Figure 3.

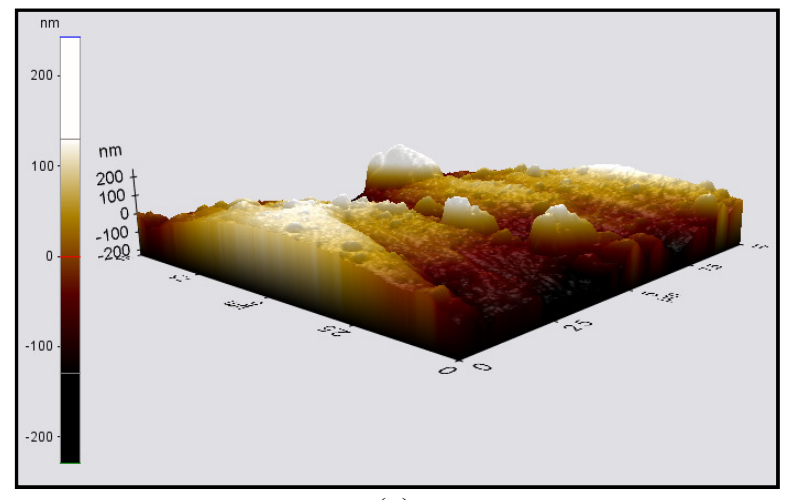

(a)

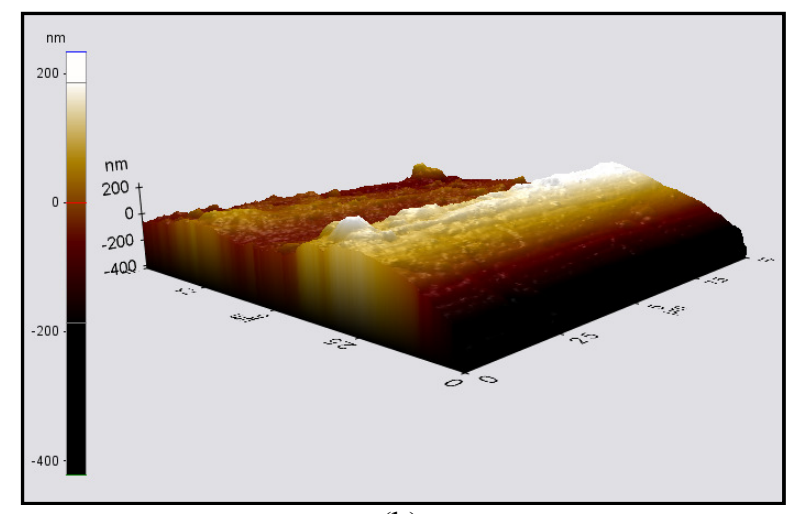

(b)

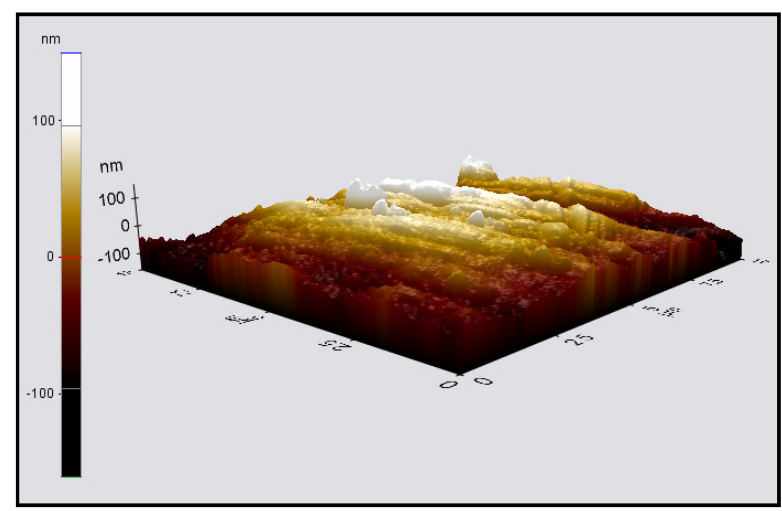

(c)

Figure 3. 3D observation on $\mathrm{FeCrAl}$ a) untreated, b) ultrasonic treatment with $\mathrm{SiC}$, c) ultrasonic treatment with $\mathrm{Al}_{2} \mathrm{O}_{3}$.
Table 2 .

Mean roughness of FeCrAl.

\begin{tabular}{ll} 
Materials & $\begin{array}{l}\text { Mean } \\
\text { Roughness, } \\
\text { Ra (nm) }\end{array}$ \\
\hline FeCrAl untreated & 31.409 \\
\hline FeCrAl ultrasonic treatment with $\mathrm{SiC}$ & 15.790 \\
\hline FeCrAl ultrasonic treatment with $\mathrm{Al}_{2} \mathrm{O}_{3}$ & 34.470 \\
\hline
\end{tabular}

In contrast with the expected result, according to AFM roughness test results; profile, mean roughness, and $3 \mathrm{D}$ topography images, the $\mathrm{FeCrAl}$ treatment with $\mathrm{Al}_{2} \mathrm{O}_{3}$ has the highest surface roughness compared the two others. It can be estimated that the roughness of $\mathrm{FeCrAl}$ resulted from treatment using ultrasonic approach, assisted with $\mathrm{SiC}$ and/or $\mathrm{Al}_{2} \mathrm{O}_{3}$ powders depend on the particle size and homogeneity of the powders.

\section{B. The Influence of Ultrasonic Treatment on FeCrAl Surface Area}

Figure 4 shows the grain area of $\mathrm{FeCrAl}$ which were (a) untreated, (b) ultrasonic treatment with $\mathrm{SiC}$, (c) ultrasonic treatment $\mathrm{Al}_{2} \mathrm{O}_{3}$ were taken using AFM, respectively. These images resulted from $10 \mu \mathrm{m} \times 10 \mu \mathrm{m}$ random scanning area of each specimen. The grain numbers on FeCrAl ultrasonic treatment with $\mathrm{SiC}$ was the highest, followed by FeCrAl untreated, and the lowest was $\mathrm{FeCrAl}$ ultrasonic treatment with $\mathrm{Al}_{2} \mathrm{O}_{3}$. Whereas the higher grain area was $\mathrm{FeCrAl}$ ultrasonic treatment with $\mathrm{Al}_{2} \mathrm{O}_{3}$, then $\mathrm{FeCrAl}$ untreated, and the smallest was $\mathrm{FeCrAl}$ ultrasonic treatment with $\mathrm{SiC}$. The mean grain area and grain numbers from AFM examination of $\mathrm{FeCrAl}$ is presented in Table 3 .

Table 3.

Mean of grain area of FeCrAl.

\begin{tabular}{lcc}
\hline Materials & $\begin{array}{c}\text { Grain } \\
\text { numbers }\end{array}$ & $\begin{array}{c}\text { Mean area, } \\
\left(\boldsymbol{\mu \mathbf { m } ^ { 2 } )}\right.\end{array}$ \\
\hline FeCrAl untreated & 172 & $5.412 \times 10^{-1}$ \\
\hline $\begin{array}{l}\text { FeCrAl ultrasonic } \\
\text { treatment with } \mathrm{SiC}\end{array}$ & 183 & $5.058 \times 10^{-1}$ \\
\hline $\begin{array}{l}\text { FeCrAl ultrasonic } \\
\text { treatment with } \mathrm{Al}_{2} \mathrm{O}_{3}\end{array}$ & 167 & $5.599 \times 10^{-1}$ \\
\hline
\end{tabular}

Table 4.

Surface area of FeCrAl.

\begin{tabular}{|c|c|c|c|}
\hline Materials & Grain numbers & $\begin{array}{l}\text { Mean of half nodules } \\
\text { surface area, }\left(\mu \mathrm{m}^{2}\right)\end{array}$ & Total surface area, $\left(\mu \mathrm{m}^{2}\right.$ \\
\hline $\mathrm{FeCrAl}$ untreated & 172 & $10.82 \times 10^{-1}$ & $1861.73 \times 10^{-1}$ \\
\hline FeCrAl ultrasonic treatment with $\mathrm{SiC}$ & 183 & $10.12 \times 10^{-1}$ & $1851.96 \times 10^{-1}$ \\
\hline FeCrAl ultrasonic treatment with $\mathrm{Al}_{2} \mathrm{O}_{3}$ & 167 & $11.20 \times 10^{-1}$ & $1870.40 \times 10^{-1}$ \\
\hline
\end{tabular}




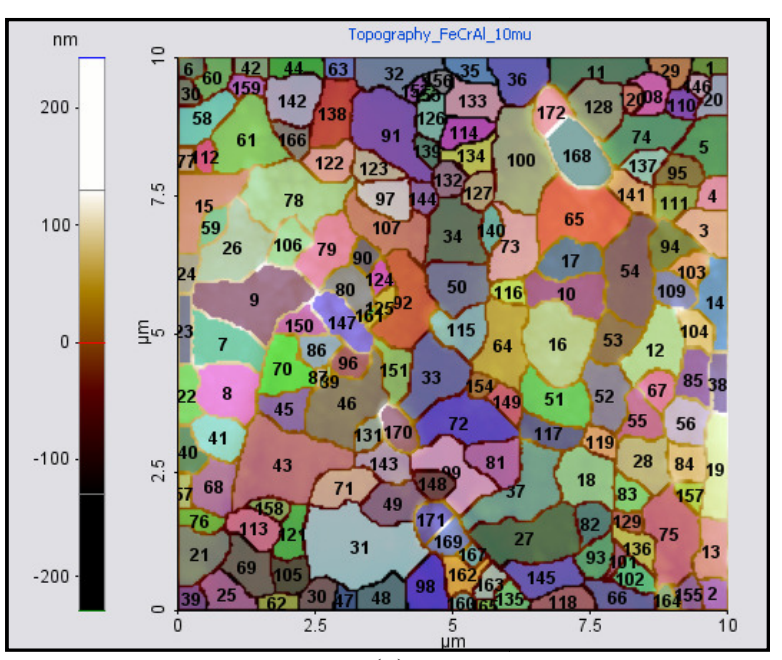

(a)

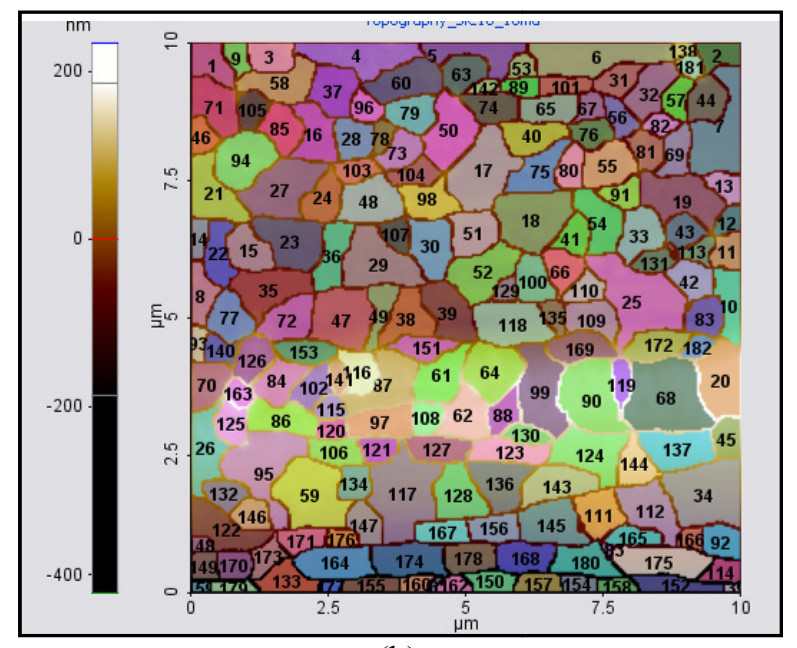

(b)

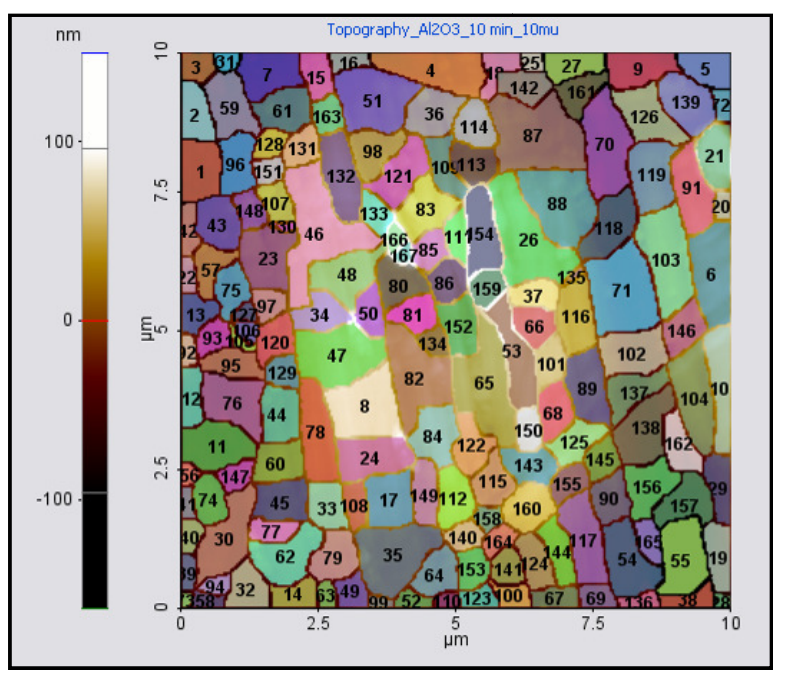

(c)

Figure 4. Grain area of $\mathrm{FeCrAl}$ a) untreated, b) ultrasonic treatment with $\mathrm{SiC}$; c) ultrasonic treatment with $\mathrm{Al}_{2} \mathrm{O}_{3}$.

The total surface area of $10 \mu \mathrm{m} \times 10 \mu \mathrm{m}$ scanning $\mathrm{FeCrAl}$ area obtained from a half area multiplied by grain numbers, which presented in Table 4. From the Table, it can be seen that the
FeCrAl treatment with $\mathrm{Al}_{2} \mathrm{O}_{3}$ resulted the highest total surface area.

The surface area acts as the main role on the catalyst reaction effective. In order to accommodate the catalyst in significant amounts, substrate must be provided with a high surface area. Twigg [19] suggested that the design of substrate must provide a maximum superficial surface area that can be presented to the exhaust gas, as it is upon this surface that the catalytic coating is applied, and on which the pollutant and reactant gases must impinge in order to react.

The AFM technique results (Table 2 and 4) show that the $\mathrm{FeCrAl}$ ultrasonic treatment with $\mathrm{Al}_{2} \mathrm{O}_{3}$ was rougher than with $\mathrm{SiC}$ and the surface area followed linearly. It estimated that the roughness of $\mathrm{FeCrAl}$ resulted from treatment using ultrasonic approach, assisted with $\mathrm{SiC}$ and/or $\mathrm{Al}_{2} \mathrm{O}_{3}$ powders also depend on the particle size and homogeneity of the powders.

\section{The Influence of Ultrasonic Treatment on Surface Morphology of FeCrAl and Its Chemical Composition}

Figure 5 reveals SEM images and EDS results of $\mathrm{FeCrAl}$ substrates which were (a) untreated, (b) ultrasonic treatment with $\mathrm{SiC}$, and (c) ultrasonic treatment with $\mathrm{Al}_{2} \mathrm{O}_{3}$ powders, respectively. The morphology of the FeCrAl untreated substrate forms a line texture along the roller manufacturing process direction. On the other hand, the morphology of the $\mathrm{FeCrAl}$ substrate treatment with $\mathrm{Al}_{2} \mathrm{O}_{3}$ and/or $\mathrm{SiC}$ showed many nodules, and a number of dimples were formed. The different textures of $\mathrm{FeCrAl}$ surface obviously describe the different surface roughness, and have been clarified using AFM in the discussion before.

The $\mathrm{SiC}$ grains also observable on the $\mathrm{FeCrAl}$ ultrasonic treatment with $\mathrm{SiC}$ powders (Figure 5.b) and $\mathrm{Al}_{2} \mathrm{O}_{3}$ grain on the FeCrAl ultrasonic treatment with $\mathrm{Al}_{2} \mathrm{O}_{3}$ powders (Figure 5.c). To clarify the chemical components adhered on each FeCrAl the EDS technique was implemented.

The arrow-sign at figure 5.a shows the standard $\mathrm{FeCrAl}$ foils chemicals component. While on FeCrAl ultrasonic treatment with $\mathrm{SiC}$ powders (Figure 5b), the arrow-sign indicates $\mathrm{SiC}$ grains. Meanwhile, on $\mathrm{FeCrAl}$ ultrasonic treatment with $\mathrm{Al}_{2} \mathrm{O}_{3}$ powders (Figure 5.c), the point with arrow-sign indicates the $\mathrm{Al}_{2} \mathrm{O}_{3}$ grains. It can be an evidence to the influenced of ultrasonic treatment on chemical composition of FeCrAl surface, although the percentage of each chemicals is not displayed.

The $\mathrm{Al}_{2} \mathrm{O}_{3}$ and $\mathrm{SiC}$ powders stick on $\mathrm{FeCrAl}$ after ultrasonic treatment process was a proof that 
the jet flush energy of ultrasonic irradiation promoted the powders to bond on the substrate. It is estimated the amount of the adhered powders will increase with the increase of the ultrasonic treatment duration. Then if the specimen is oxidized, the $\mathrm{Al}_{2} \mathrm{O}_{3}$ and $\mathrm{SiO}$ will be formed on $\mathrm{FeCrAl}$ substrate. It was known that $\mathrm{Al}_{2} \mathrm{O}_{3}$ and $\mathrm{SiO}$ are include in the type of higher surface area catalyst carrier [3].

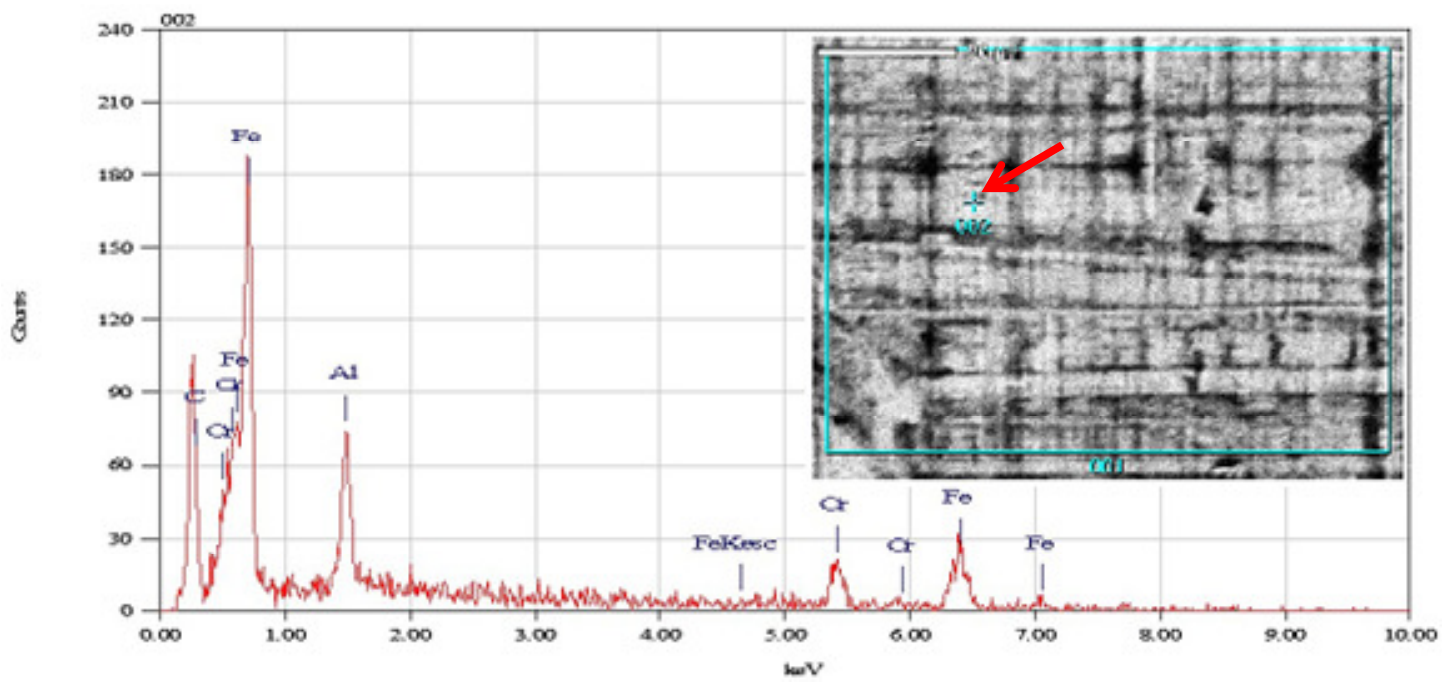

(a)

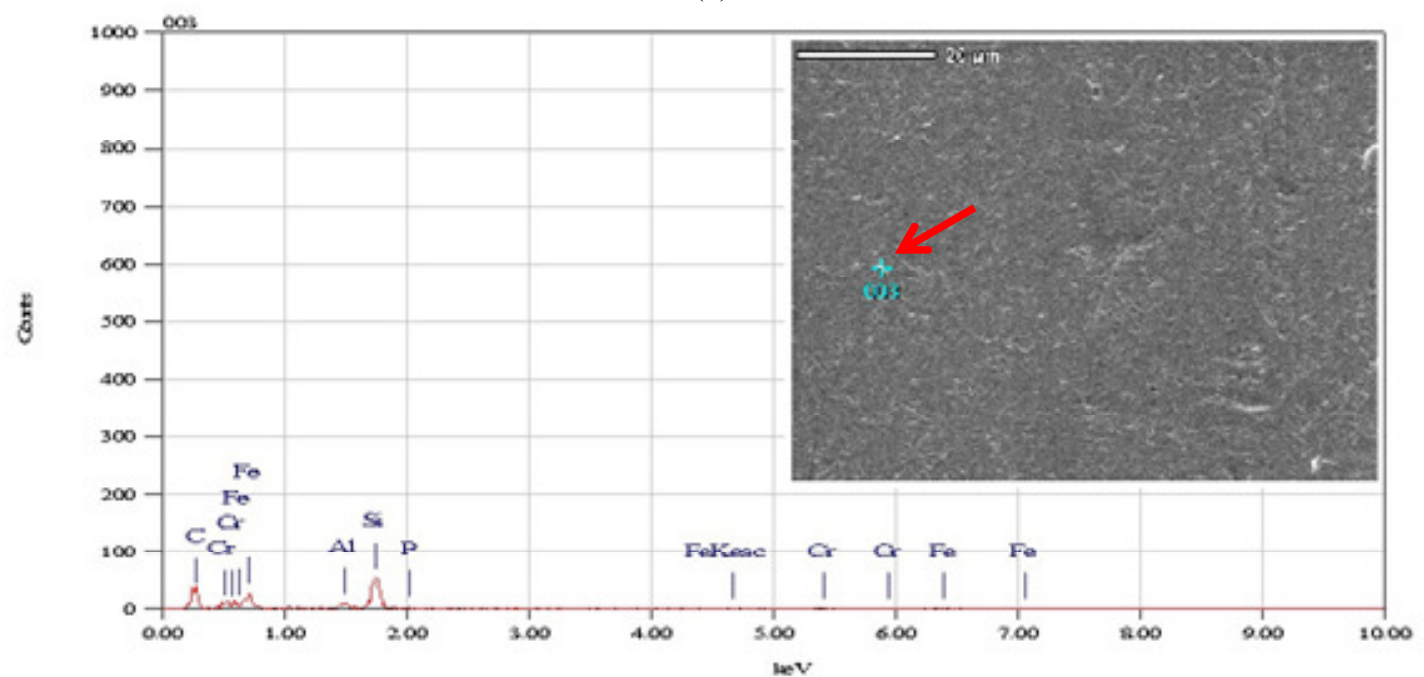

(b)

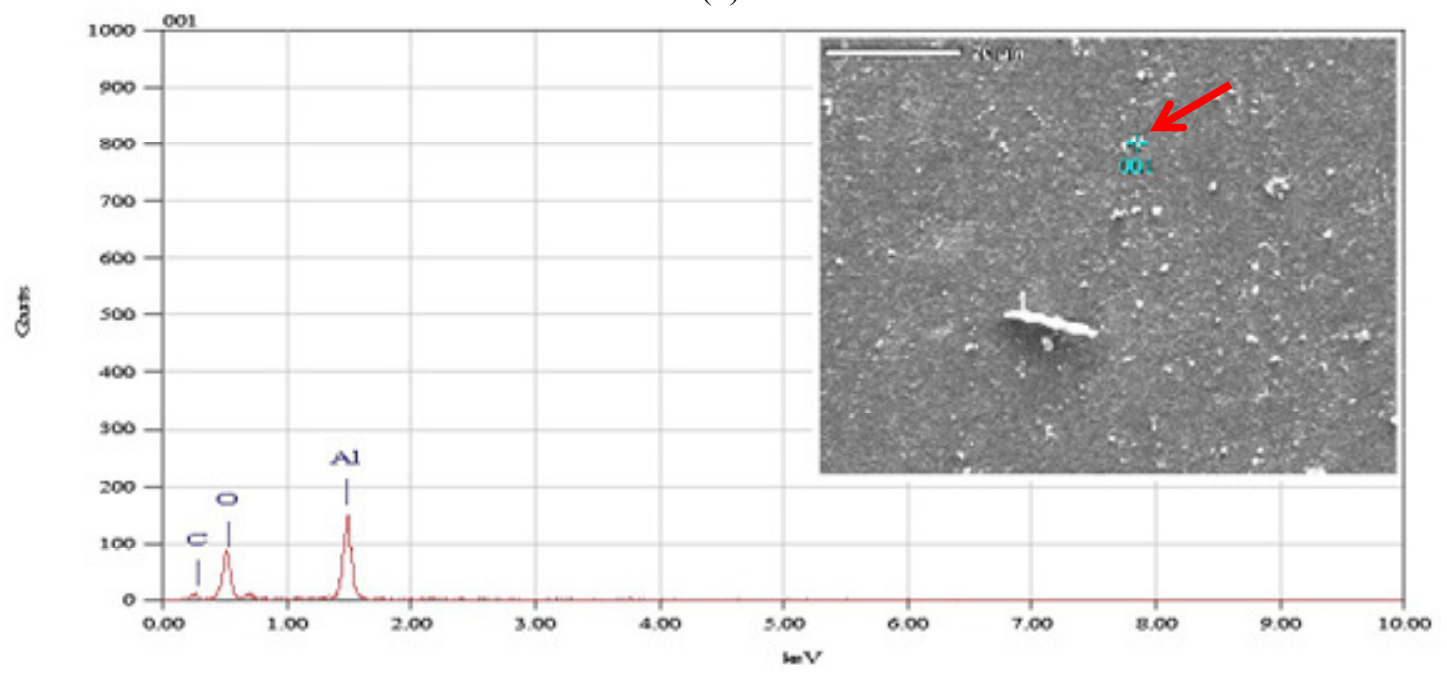

(c)

Figure 5. Morphology and EDS of FeCrAl a) untreated, b) ultrasonic treatment with $\mathrm{SiC}$; c) ultrasonic treatment with $\mathrm{Al}_{2} \mathrm{O}_{3}$. 


\section{CONCluSion}

The surface treatment using ultrasonic assisted with $\mathrm{Al}_{2} \mathrm{O}_{3}$ powders for 10 minutes increased the surface roughness of $\mathrm{FeCrAl}$ substrate better than $\mathrm{SiC}$ powders. The greater surface area of $\mathrm{FeCrAl}$ substrate was achieved using 10 minutes ultrasonic treatment assisted with $\mathrm{Al}_{2} \mathrm{O}_{3}$ powders, compared to one assisted with $\mathrm{SiC}$ powders. The $\mathrm{Al}_{2} \mathrm{O}_{3}$ and $\mathrm{SiC}$ powders were successfully attached on FeCrAl substrate after ultrasonic treatment process. These achievements will be useful for catalytic converter production using $\mathrm{FeCrAl}$ as a substrate.

\section{ACKNOWLEDGEMENT}

The authors would like to thank the Ministry of Higher Education Malaysia and Universiti Tun Hussein Onn Malaysia (UTHM) through the funding support of Fundamental Research Grant Scheme (FRGS), Vot no. 0265 and 0361. The authors would also like to thank the Thyssen Krupp VDM GmbH for supplying material.

\section{REFERENCES}

[1]. Bruck, R., Emitec GmbH., Lohmar. "Development Status of Metal Substrate catalysts" in Material Aspects in Automotive Catalytic Converters, Bode, H., Wiley-VCH Verlag $\mathrm{GmbH} \& \mathrm{Co}$. KgaA, 2002, pp. 18-30.

[2]. Nicholls, J. R., and Quadakkers, W. J. "Materials Issues Relevant to the Development of Future Metal Foil Automotive Catalytic Converters" in Material Aspects in Automotive Catalytic Converters, Hans Bode, Wiley-VCH Verlag GmbH \&Co. KgaA, 2002, pp 3148.

[3]. Heck. R. M. et al, Catalytic Air Pollution Control Commercial Technology $3^{\text {rd }}$ ed, John Wiley \& Sons, Inc., 2009.

[4]. Bharali. P., "Automotive Exhaust Catalysis", N. E. Quest, 3, Issue 4, pp 4043, 2010.

[5]. Sun, H., et al, "Preparation of well-adhered $\gamma-\mathrm{Al}_{2} \mathrm{O}_{3}$ washcoat on metallic wire mesh monoliths by electrophoretic deposition", Applied Surface Science, 253, pp. 33033310, 2007.

[6]. Whu, X., et al., "Influence of an aluminized intermediate layer on the adhesion of a $\gamma-\mathrm{Al}_{2} \mathrm{O}_{3}$ washcoat on FeCrAl", Surface and Coatings Technology, 190, pp. 434-439, 2005.
[7]. Mellali, M., et al., "Influence of substrate roughness and temperature on the adhesion/cohesion of alumina coatings", Surface and Coatings Technology, 81, pp. 275-286, 1996.

[8]. Henke, L., et al., "An AFM determination of the effects on surface roughness caused by cleaning of fused silica and glass substrates in the process", Biosensors and Bioelectronics, 17, pp. 547-555, 2002.

[9]. Ortel, E., et al., "Influence of steel substrate roughness on morphology and mesostructure of $\mathrm{TiO} 2$ porous layers produced by template-assisted dip coating", Microporous and Mesoporous Materials, 127, pp. 17-24, 2010.

[10]. Panin, A.V., et al., "The effect of ultrasonic treatment on mechanical behavior of titanium and steel specimens", Theoretical and Applied Fracture Mechanics, 41, pp. 163-172, 2004.

[11]. Zhang, F., et al., "Surface treatment of magnesium hydroxide to improve its dispersion in organic phase by the ultrasonic technique", Applied Surface Science, 253, pp. 7393-7397, 2007.

[12]. Liu, L., et al., "Ultrasonic treatment of aramid fiber surface and its effect on the interface of aramid/epoxy composites", Applied Surface Science, 254, pp. 25942599, 2008.

[13]. Paniwnyk, L., Cobley, A., "Ultrasonic Surface Modification of Electronics Material", Physics Procedia, 3, pp. 11031108, 2010.

[14]. Sebayang, D., et al., "Influence of difference deposition technique of nickel on the FeCrAl metallic monolith" in Proceedings of the Malaysian Metallurgical Conference '09 (MMC'09), UniMap Perlis Malysia, 2009.

[15]. Sebayang, D., et al., "Effect of pretreatment using ultrasonic technique with $\mathrm{SiC}$ or $\mathrm{Al}_{2} \mathrm{O}_{3}$ on high temperature oxidation behavior of the FeCrAl" in Proceeding of the $14^{\text {th }}$ International Conference on Applied Mechanics and Mechanical Engineering AMME-14, Egypt, 25-27 May, Military Technical College Cairo, 2010.

[16]. Sebayang, D. Et al., "NiO development on FeCrAl substrate for catalytic converter ultrasonic and nickel electroplating methods", To be published in the 2010 International Conference on Material and Manufacturing Technology (ICMMT 2010), Chongqing China, 17-19 September 
2010, Advanced Materials Research Journal.

[17]. "Aluchrom Yhf Material Data Sheet", (2008), No. 4049 March 2008". Germany: ThyssenKrupp VDM.

[18]. Saez, V. and Mason, T.J., "Sonoelectrochemical synthesis of nanoparticle", Molecules, pp. 1420-3049, 2009.
[19]. Twigg, M.V. and Webster, D.E. "Metal and Coated Metal Catalysts" in Structured Catalysts and Reactors $2^{\text {nd }}$ ed, Cybulski, A., Moulijn, J.A. Taylor \& Francis Group, USA, 2006 